\title{
Social Media Adoption among Public Relations Practitioners in Qatar
}

\author{
Mohamed Kirat, PhD \\ Professor, Department of Mass Communication \\ College of Arts and Sciences \\ Qatar University, PO. Box: 2713 \\ Doha, Qatar
}

\begin{abstract}
This study looks at how PR practitioners in the state of Qatar are adopting social media and how they are using it to perform various PR activities. This paper builds on Wright and Henson and Alikilic and Atabek studies. A selfadministered questionnaire was distributed to public relations practitioners working for government and private organizations in the country. Two hundred and thirty three PR professionals from 48 institutions participated in the study. The questionnaire addressed the following issues: Patterns of social media usage by PR practitioners for public relations activities; social media and its impact on the practice of public relations; social media impact on organization's publics, and entity in charge of monitoring and managing social media in the organization. Findings of the study showthat public relations practitioners in Qatar are highly aware of the importance of social media in enhancing public relations activities. On the social and emerging media impact on the organization's activities findings indicate that there is a significant impact on the communication activities of the organization.As for the social media use for public relations activities, findings of the study show that corporate website comes first with $75.1 \%$ followed respectively by electronic mail $72.2 \%$, Intranet $35.7 \%$, social networks $24.6 \%$, video and photo sharing $20.6 \%$; blogs $19.8 \%$, forum and news groups $18.4 \%$, instant messaging $17.6 \%$ and podcast, wikis and social bookmarking $11.7,11.7$ and 11.6 respectively. Public relations practitioners in Qatar believe social media has a considerable impact on organization's publics, and $90 \%$ of them think that public relations department should monitor and manage social media in the organization.
\end{abstract}

Keywords: Online PR, use of social media, impact of social media on PR, monitoring social media, organization exposure, customers' feedback.

\section{Introduction}

The emergence of social media has impacted more than just communication practices - it has revolutionized the patterns of communication that people adopted for decades if not centuries. The new media provided new platforms of communication that allow people to receive and send messages instantly. For PR professionals, social media provided a democratic environment to perform transparent, frank, direct and democratic public relations. Social media have made the access and the dissemination of news and information easy to all. As a result,individuals and organizations can promote and persuade using the various platforms and tools of social media, potentiallyreaching anyone in cyberspace. For public relations professionals, social media empowers two way symmetrical communications with various publics and stakeholders.

The number of social media users worldwide in 2019 reached3.484 billion, up 9\% year-onyear.(https://www.smartinsights.com/social-media-marketing/social-media-strategy/new-global-social-media-research/) .There are over 2.38 billion monthly active users (MAU) of Facebook as of March 31, 2019, of which 1.56 billion on average log onto Facebook daily and are considered daily active users (Facebook DAU) for March 2019. (https://zephoria.com/top-15-valuable-facebook-statistics/). While previousliterature indicates the problems associated with growing social media usage, various organizations engaged heavily in using social media as a way to enhance, sustain, and defend corporate image. Experts in social media usage estimate that during 2018-2021, the number of companies that use social media to interact with customers will more than triple. Despite concerns, social media users in business and consumer markets are increasingly employing social media to advertise and communicate. The emergence of social media has changed the way firms manage relationships and interactions with their audiences. Social media in the forms of online word-of-mouth forums, blogs, discussion boards, e-mail, chat rooms, product or service review websites and social networking websites like Twitter and Facebook provide an inexpensive and easyway to increase the flow of information to a variety of internal and external publics and stakeholders. This enhances and perpetuates both transparency and accountability, which are vital to building, maintaining, anddefending a corporate image in an environment where individuals are actively engaging in online conversations. 
With the emergence and growth of social media, it is essential that organizations make a rational and efficient use of the new platforms to sustain their corporate image and maximize their performance.

\section{Social Media and the Digitalization of a Profession}

The Internet has changed the way people communicate and make contact with each other. Communication is becoming more fluid, faster and available to everyone. The practice of public relations has no other choice but to respond accordingly. Recent research suggests that public relations professionals are adopting online tools increasingly and rapidly. In this regards, Wright and Hinsen argue

For several years, the authors of this article have conducted an annual trend study examining the impact social media are having on public relations throughout the world (2008a, 2008b \& 2009). Results clearly show that social media are bringing dramatic changes to many aspects of the field. The findings of these studies also suggest that the development of various new technologies has significantly empowered a wide variety of strategic publics by giving them dynamic new media many are using to communicate effectively with a variety of internal and external audiences. (Wright and Hinsen, 2009a:4).

According to a 2009 Public Relations Society of America (PRSA) "Examining How Public Relations PractitionersActually Are Using Social Media" study, the majority of public relations professionals assert that the use of communication technology has made their job easier by expediting the circulation of information to reach larger audiences. Social media not only allows public relations practitioners to reach out to, and engage their publics in conversation, but also provides a channel to strengthen media relations. Social media have been adopted from its inception by public relations, PR practitioners perceive social media positively with respect to strategic communication. Social media are the creation of platforms that connect people together, provide an opportunity to produce and share content with others, extract and process community knowledge and share it back. Face book, Myspace, Twitter, LinkedIn, Foursquare and Flicker are among the most popular social network services.

Social media is reorganizing the profession of public relations. Since the advent of Internet, PR is becoming more and more online and virtual; many of its activities areperformed through the net. Modern technology transforms the way we send, receive and process information. Social media or online networking sites, have been heralded as groundbreaking interactions which allow for networked communication to occur instantaneously. Social media enable PR practitioners to share content, opinions, experiences, insights, views, feedback, and media themselves. Social media sites encourage and foster two-symmetrical communication among its participants. Using social media by PR practitioners allow them to reach and interact with multiple publics and stakeholders, thus opening the opportunities and possibilities for mutually beneficial relationships. The Internet has dramatically changed the media environment, leading journalists to gather news information online. This shifting trend also has changed the way organizations communicate with the news media. An increasing number of public relations practitioners are using various Internet technologies (e.g. e-mails, websites, multimedia news releases, online pressrooms, RSS feeds, and social media) to better communicate with journalists and to enhance their media relations. In particular, growing numbers of corporate/organizational websites provide online press rooms that provide journalists with access to essential organization information and media material such as press releases, fact sheets, backgrounders, newsletters, brochures, photographs and audio/video clips, and many downloadable collateral materials. This makes life easier for journalists who can access to a wide range of information to write their stories. According to Pettigrew and Rebar 495 companies of the Fortune 500, companies have online newsrooms on their websites. More than $95 \%$ of journalists indicated that it is important for a company or organization to have an online newsroom available to the press. Both journalists and public relations practitioners believe that online newsrooms are an indispensable communication channel.

Most social media sites offer comments, data, news, information, and story ideas that PR practitioners may use to perform their tasks and activities such as media relations, communications with various publics and stakeholders, social corporate responsibility, publicity and image building. Seitel argues:

As the number of world's citizens using the Internet expands exponentially, it is urgent that public relations professionals understand the new technology and its capabilities and increase their competence in employing and monitoring it. Those who can blend the traditional skills of writing and media and communications knowledge with the online skills of the Internet will find a rewarding calling in the practice of publics relations in the 21st century.(Seitel, 2006:34).

These changes also are taking place with some of the trade magazines that serve the public relations industry. In 2009, $P R$ Week, considered by many to be the nation's most dominant public relations trade publication, changed its weekly print edition into an online format, although it does produce a printed magazine each month. 
New media have "changed the rules of the game in every part" of strategic communication according to many communication and PR experts and researchers, who claim that over the past decade these new communication vehicles have not only turned upside down everything people knew about communication but also have dramatically changed the business of managing relationships. Findings of the noted Authentic Enterprise Report of the Arthur W. Page Society give the new communication media credit for dramatically changing the ways in which stakeholders are empowered. The Page Society's most recent report - Building Belief: A New Model for Activating Corporate Character and Authentic Advocacy (2012) - explains how the roles and functions of chief communications officers of major companies are changing given advances in new technologies among other things. Social media are being utilized on an ever-increasing basis by corporations and other organizations .More than two-thirds of the current Fortune 2000 companies are using social networking sites. Advocacy groups are advancing their public relations agendas via Facebook. As mentioned previously, another measure of the growth and development of social media in public relations is the level of social media activity currently displayed by various professional societies active in the field.

Annual surveys measuring how social and other emerging media are being used in public relations practice showed that the use of these new media has continued to increase each year. This has provided unique opportunities not only for those who practice public relations but also for a wide variety of strategic publics.Public relations practitioners firmly believe that these new media have enhanced public relations practice, mainly when it concerns external audiences. Results also indicate that PR practitioners believe social and other emerging media continue to improve the profession in terms of accuracy, credibility, honesty, trust and truth telling. They also think these new media effectively serve as a watchdog for traditional news media, impacting corporate and organizational transparency and advocating a transparent and ethical culture. Public relations practitioners spend between 25 to 35 percent of their workday with blogs and other social media meaning that the PR profession is getting more and more virtual and digital.

Seitel (2011) argues that Internet is an indispensable tool for the practice of public relations. To him "mastering and monitoring the Internet have become a front-burner priority for public relations professionals". Seitel asserts:

In the $21^{\text {st }}$ century, such new techniques as blogging for promotional product buzz, setting up "blog carnivals" to inform a community about a particular topic, creating search-friendly Web sites and search-optimal keywords, podcasting, video casting, and orchestrating word-of-mouth marketing campaigns are all part of the public relations practitioner's online tool kit. (Seitel, 2011:409).

\section{Related Studies}

Wright and Hinson did a longitudinal study on the emerging media use in public relations between 2006 and 2013. Findings of the study suggest that public relations practitioners are using more and more social media in their activities. They assert:

Results of our eighth annual survey measuring how social and other emerging media are being used in public relations practice found the use of these new media has continued to increase each Year providing unique opportunities not only for those who practice public relations but also for a wide Variety of strategic publics who have been given dynamic new communication vehicles many are using Effectively with a variety of internal and external audiences. .(Wright and Hinson,2013).

According to the authors, the new tools are providing unique opportunities for both PR professionals and for a wide variety of strategic publics

Results also indicate those who practice public relations believe social and other emerging media continue to improve in terms of accuracy, credibility, honesty, trust and truth telling. They also think these new media effectively serve asa watchdog for traditional news media, impacting corporate and organizational transparency and advocating a transparent and ethical culture.

Ozlem Alikilic and Umit Atabek (2012) looked at "Social media adoption among Turkish public relations professionals: A survey of practitioners". The authors used an online questionnaire sent to 158 members of the Turkish Public Relations Association (TUHID).The authors concluded that:

Internet and social media tools in Turkey, like social networks, blogs, and online videos have revolutionized the dynamics of public relations and social media... This exponential rise in interest of social media seems to be pressuring PR professionals to integrate these tools into their work. Research findings show that public relations professionals in Turkey have started to facilitate dialogs with their publics by using social media. (Alikilic and Atabek, 2012:62)

Wilson and Supa looked at the effect of Twitter on the public relations-journalist relationship (Wilson and Supa,2013). The authors used a questionnaire covering a sample of 340 journalists and 291 public relations practitioners. Of those that completed the survey 48 (14\%) were journalists and $66(22.6 \%)$ public relations practitioners. 
Findings of the study suggest that the benefits of Twitter as an information-sharing platform were clearly recognized as important for both journalism and public relations.

You and Kim (2013) examined the use of online newsrooms on U.S. state tourism websites. They did a content analysis of 50 state tourism websites to investigate the availability of online newsrooms as well as their contents and overall usability. Findings of the study show that "the average number of social media use by the 50 state tourism offices is 4.04, and the most often used social media are Facebook (50 States), Twitter (49 States), YouTube (36 States), and Flickr (29 States)". (Yoo and Kim, 2013:539).

\section{Research Questions}

RQ1: What are the patterns of social media usage by public relations practitioners in Qatar ?

RQ2: What social media tools are used by public relations practitioners in Qatar, and what are the most used among them?

RQ3: To what extent have social media affected the practice of public relations?

RQ4: What are the publics and stakeholders that the organization communicate with through social media?

RQ5: Which entity should monitor and manage social media in the organization?

RQ6: What is the amount of time spent with blogs and other social media while performing PR activities?

\section{Methodology}

This research builds on Wright and Hinson and Alikilic and Atabek studies. The convenience sample was used.A selfadministered questionnaire was distributed to public relations practitioners working for Qatari government departments, as well as, semi private and private companies.Two hundred and thirty three PR professionals from 48 institutions participated in thisstudy. The questionnaire addressed the following issues: What social media tools are used by public relations practitioners in Qatar, and what are the most used among them; Use of social media for public relations activities; social media and its impact on the practice of public relations; Kind of stakeholders communicated with trough social media; party in charge of monitoring and managing social media in the organization, and time spent using social media in the job.

\section{Findings}

Sixty seven percent of the public relations practitioners in Qatar are females. Almost two thirds $(30.5 \%)$ of the respondents are aged less than 31 years old. The majority of the practitioners are Qataris $(84.5 \%)$. As for the level of education, 70.8 percent of the respondents of this study hold a bachelor degree; and 75 percent of them majoring in media studies. Eighty seven percent of PR practitioners in Qatar use information technology daily, 81.1 percent use "very much" Internet in their work. All the PR practitioners 'organizations have a website. Ninety percent of the respondents said the media use the website for news and information; and $72.1 \%$ said they use social networks to perform public relations activities. Public relations practitioners of this study come from media organizations (16\%), oil and gas industry (15\%), higher education institutions (14\%), government service departments (14\%), tourism industry $(12 \%)$, health institutions (10\%). Other sectors were represented such as telephony, sports, charitable organizations and cultural and social institutions (table:3).

\section{Demographics of Public Relations Practitioners}

\begin{tabular}{|l|c|}
\hline Female & $67 \%$ \\
\hline Male & $33 \%$ \\
\hline Age Less than 31 & $30.50 \%$ \\
\hline $31-45$ & $51.70 \%$ \\
\hline More than 45 & $27.80 \%$ \\
\hline Experience Less than 7 & $43.91 \%$ \\
\hline (years) 8-18 & $45.02 \%$ \\
\hline More than 18 & $11.07 \%$ \\
\hline
\end{tabular}

Table: 1- Gender, age, and Job experience of PR practitioners ( $\mathrm{N}=233)$ 


\begin{tabular}{|l|c|}
\hline High school & 32.1 \\
\hline Bachelor & 65.4 \\
\hline Master & 1.9 \\
\hline PhD & .6 \\
\hline Total & 100.0 \\
\hline
\end{tabular}

Table:2- PR practitioners' level of education (in $\%, N=233$ )

\section{Employers of Public Relations Practitioners}

\begin{tabular}{|l|c|}
\hline Employers & $\%$ \\
\hline Media organizations & 16 \\
\hline Oil and Gas & 15 \\
\hline Higher education & 14 \\
\hline Government Service departments & 14 \\
\hline Tourism & 12 \\
\hline Health sector & 10 \\
\hline Telephony & 8 \\
\hline Sports & 5 \\
\hline Charitable organizations & 3 \\
\hline Cultural and social institutions & 3 \\
\hline
\end{tabular}

Table:3-Employers of the sample. $(\mathrm{N}=233)$

\section{Social media Use By Public Relations Practitioners}

As for the social media use for public relations activities, table 4 shows that Corporate web sitescome first with(75.1\%), followed respectively by electronic mail (72.2\%), Intranet (35.7\%) ; social networks (24.6\%), video and photo sharing $(20.6 \%)$, blogs $19.8 \%$, forum and news groups $18.4 \%$. Respondents also mentioned instant messaging 17.6\%; podcast (11.7\%); wikis (11.7\%) social bookmarking $11.6 \%$. These figures indicate that Public relations practitioners are highly aware and motivated to use social media in their activities.

\begin{tabular}{|l|c|}
\hline Social media & $\%$ \\
\hline Corporate web sites & 75.1 \\
\hline Electronic mail & 72.2 \\
\hline Intranet & 35.7 \\
\hline Social networks & 24.6 \\
\hline Video and photo sharing & 20.6 \\
\hline Blogs & 19.8 \\
\hline Forum/news groups & 18.4 \\
\hline Instant messaging & 17.6 \\
\hline Podcast & 11.7 \\
\hline Wikis & 11.7 \\
\hline Social bookmarking & 11.6 \\
\hline
\end{tabular}

Table:4-Use of social media for public relations activities.( $\mathrm{N}=233)$

On the social and emerging media impact on the organization's activities findings from table 5 shows that there is an impact on the communication activities of the organization 3.23 over 5, where five means strongly agree; 3.27 on handling external relations and 3.01 on dealing with internal communication. These scores (means) indicate that public relations practitioners believe that social media are used to achieve various tasks and missions of public relations in the organizations in particular and the society in general. Thus, they are adopting themselves and the profession to the digital society in which they live. 


\begin{tabular}{|l|c|}
\hline Activity & Mean \\
\hline Communicates & 3.23 \\
\hline Handles external communication & 3.27 \\
\hline Handles internal communication & 3.01 \\
\hline
\end{tabular}

Table: 5-Types of PR activities handled by social media. $(\mathrm{N}=233)$

Note: Mean scores are based on responses to five-point Likert-type scales where "1" = "Strongly Disagree," and "5" = "Strongly Agree.

On the social media impact on the organization's activities, table 6 shows strong means scores. Respondents believe that social media have promoted and enhanced the practice of public relations (4.69/5). Public relations practitioners of this study assert that social media including blogs influence mainstream media $(4.11 / 5)$

\begin{tabular}{|l|c|}
\hline Activity & Mean \\
\hline Social media have enhanced the practice of public relations? & 4.69 \\
\hline $\begin{array}{l}\text { Social media (including blogs) influence the traditional } \\
\text { mainstream media? }\end{array}$ & 4.11 \\
\hline Traditional mainstream media influence social media (including blogs)? & 3.50 \\
\hline
\end{tabular}

Table: 6- Social media impact on the organization's activities ( $\mathrm{N}=233)$

\section{Stakeholders communicated with Through Social Media}

Table 7 shows what kind of stakeholders are targeted through social media . News media comes first with $90 \%$ of the respondents saying that the organization communicate with journalists through social media; respectively internal public and staff and current customers and clients come second with $80 \%$. Seventy percent of the interviewees mentioned the use of social media to reach potential customers and clients and local community. The organization communicates with investors and suppliers through social media was mentioned by $50 \%$ of the PR practitioners of this study. Business partners and retirees were mentioned by respondents of this study by $45 \%$ and $40 \%$ of the respondents of this study. These findings indicate that key publics and stakeholders of the organization are targeted through social media which means a rational use of the new media to communicate and perform major public relations activities by various organizations in Qatar.

\begin{tabular}{|l|c|}
\hline Stakeholder & $\%$ \\
\hline News media & 90 \\
\hline Internal public and staff & 80 \\
\hline Current customers and clients & 80 \\
\hline Local community & 70 \\
\hline Potential Customers and Clients & 70 \\
\hline Investors & 50 \\
\hline Suppliers & 50 \\
\hline Business partners & 45 \\
\hline Retirees & 40 \\
\hline
\end{tabular}

Table: 7- Publics and stakeholders Whom the organization communicate with through social media( $\mathrm{N}=233)$

\section{Who should monitor and manage blogs and social media in your organization?}

"In your opinion, which of the following functions should be responsible for monitoring and managing blog and social media communication in your organization?". On who should monitor and manage blogs and social media table 8 shows that the majority of the respondents of this study (72\%) said the PR department should assume such task; IT department was mentioned by $10 \%$. human resources $8 \%$, and marketing $4 \%$. 


\begin{tabular}{|l|c|}
\hline Monitoring entity & $\%$ \\
\hline PRDepartment & 72 \\
\hline IT Department & 10 \\
\hline Human Resources & 8 \\
\hline Marketing & 6 \\
\hline Don't Know & 4 \\
\hline
\end{tabular}

Table:8-Who should monitor blogs and social media in your organization( $\mathrm{N}=233)$

Asked "On the average, approximately what percentage of your time working in public relations and communications is spent with blogs and other social media", $35 \%$ of the public relations practitioners in this study spent between 11 to $25 \%$ of their working time using social media to perform PR activities, 32\% spent between 1 and $10 \%$; $14 \%$ of the practitioners spent between 26 to $50 \%$ and 51 to $75 \%$ of their time. Three percent said they spend more than $75 \%$ of their working time and $2 \%$ said they do not use blogs and social media in their PR work. (Table:9).

\begin{tabular}{|l|c|}
\hline Time Spent & $\%$ \\
\hline None & 2 \\
\hline $1 \%-10 \%$ & 32 \\
\hline $11 \%-25 \%$ & 35 \\
\hline $26 \%-50 \%$ & 14 \\
\hline $51 \%-75 \%$ & 14 \\
\hline More than $75 \%$ & 3 \\
\hline
\end{tabular}

Table:9- Time spent with blogs and social media while working in public relations and other social media

\section{Discussion and conclusions}

According to Argenti and Barnes (2009) new media have changed the patterns of strategic communication. They changed the way organizations are communicating with their employees, publics and stakeholders. This study sought to investigate the use of social media by public relations practitioners in Qatar. Given the fact that Qatar enjoys a very high Internet penetration, as well as, a good telecommunication infrastructure, the study revealed a high level of social media adaptation to perform various public relations activities and programs. This study supports findings of previous research done on the impact of social media on Public relations practitioners.In this study, respondents affirm that they use a wide range of social media such as corporate websites, electronic mail, intranet among others in their daily activities to reach their various publics and stakeholders. On the other hand, PR practitioners in Qatar assert that social and other emerging media have changed the way their organization is communicating and dealing with publics and stakeholders. They believe that the new media has positive impact on external as well as internal communication. The communication process has been very smooth, rapid, direct and providing a large space of interactivity and dialogue between the organization and its publics.

Public relations practitioners in Qatar believe social and emerging new media have been improving the practice of public relations in terms of credibility, transparency, trust, honesty, truth telling, accuracy and accountability. The new media have a positive impact on corporate and institutional transparency thus promoting two way communication and a culture of democracy.

In terms of monitoring and managing social media in the organizations, a striking majority believe that public relations is the entity in the organization to be in charge. This research provides important insights on the adoption of social media among public relations practitioners in Qatar. This means that the widespread use of social media by public relations professionals is an international practice given the importance of the new media for both organizations, and their publics and stakeholders. One issue to be raised here is to what extent PR and Mass Communication departments are adjusting and adapting their curriculums and study plans to the new transformations in the field concerning the digitalization of the PR profession and the use of social media in the majority of PR activities and programs. In this regards Lee argues:

This study suggests that practitioners understand the tactical side of social media, butmay not be getting experience or knowledge, either in school or on the job, related to howtheir social media tactics relate to broader public relations goals. Incorporating social mediainto strategic public relations education could help new practitioners make this connection. (Lee,2013:32). 
As for the Arab world, a lot has to be done concerning textbooks and courses to provide good qualifications and training in terms of social media and virtual public relations for future graduates in the field. Another issue to be taken into consideration is social media training for public relations professionals. Organizations should focus on training their PR personnel on how to use the new tools of the digital era, which tool for what kind of activity and for what purposes, and how to measure their use and impacts.

This study shows that public relations practitioners in Qatar are engaged in the adoption of social media in its activities, thus supporting findings of earlier studies done in different countries and settings (Curtis et al., 2010; Diga \& Kelleher, 2009; Eyrich et al., 2008; Gillin, 2007; Kelleher, 2009; Kitchen \& Panopoulos, 2010; Toledano, 2010; Oettigrew \& Reber, 2010). Internet and social media tools in Qatar, like social networks, blogs, and online videos have revolutionized the dynamics of public relations.Social media have created new channelsthat replace the old media.

This rapid rise in interest of social media seems to be pressuring PR professionals to integrate these new tools into their work. Research findings show that public relations professionals in Qatar have started to facilitate dialogues with their publics by using social media. It also shows that the value of engaging in social media can be seen in every aspect of public relationstasks and activities. One can conclude that public relations professionals in Qatar have realized that, with the emergence of social media, they have no choice but to engage more and more in two way communication and to be more transparent and open with their audiences and stakeholders. Transparency and democratic conversations are very important contributions of social media. This may introduce an opportunity to public relations practitioners to influence and shape their relationships with their constituents, and to provide an environment of transparency and democracy.

\section{References}

Alikilic, Ozlem \& Umit Atabek (2012). Social Media Adoption Among Turkish Public Relations Professionals: A Survey of Practitioners. Public Relations Review, 38, 56-63.

Argent, P.A \& Barnes, C.M (2009). Digital Strategies for Powerful Communication. New York: McGraw Hill.

Komodromos, Marcos (2014) A Study of PR Practitioners'Use of Social Media Tools in Cyprus. Journal of Developmental Entrepreneurship. Vil.19, No.2, 1-9.

Lariscy, R.W., Avery, E.J., Sweetser, K.D., \& Howes, P. (2009). Monitoring Public Opinion in Cyberspace: How corporate Public Relations is Facing the Challenge. Public Relations Journal, 3(4), 1-17.

Laskin, A.V. (2012). Social media and investor relations. In S. Duhé (Ed.), New media and public

Lee, Nicole Marie (2013). The Role of New Public Relations Practitioners as Social Media Experts. Master Thesis, San Diego State University.

Liu, B.F. (2010). Distinguishing how elite newspapers and A-list blogs cover crises: Insights for managing crises online. Public Relations Review, Vol. 36, No. 1, pp. 28-34.

Marchese,J. (2007). Defining social media. June 5. Retrieved from http://www.mediapost.com/publications/?fa=Articles.showArticle\&art_aid=61442

Paine, K.D. (2009a), "Thoughts on social media and public relations. Retrieved from http://kdpaine.blogs.com/kdpaines_pr_m/2009/03/thoughts-on-social-media-and-pr.html.

Payne, K.D. (2009b). Much ado about something: Web 2.0 acceptance and use by public relations practitioners. Paper presented to the 12th Annual International Public Relations Research Conference, Coral Gables, Florida March 13.

Seitel, F.P (2006) “Know your social media”, O’Dwyer's PR Report( November): 34.

Seitel, F.P (2011) The Practice of Public Relations. Eleventh edition. Boston: Pearson.

The Top 20 Valuable Facebook Statistics- Updated June 2019.https://zephoria.com/top-15-valuable-facebook-statistics. Accessed June10,2019.

using social media. Public Relations Journal, Vol. 2, No. 3, Summer, 2009. Retrieved from

Wilson, Drew and Dustin Supa (2013) Examining Modern Media Relations: An Explanatory Study of the Effect of Twitter on the Public Relations-Journalist Relationship, Public Relations Journal, Vol.7, No.3,pp:1-20.

Wright D.K. and Hinson, M.D. (2011a). Additional exploration about the impact of social media and other new technologies on public relations. Paper presented to the 14th Annual International Public Relations Research Conference, Coral Gables, Florida, March 11.

Wright D.K. and Hinson, M.D. (2011b). A three-year longitudinal analysis trend study measuring new communications media use by public relations practitioners. A paper presented to the Annual Conference of the Public Relations Division of the Association for Education in Journalism and Mass Communication, St. Louis, Missouri, August 11. 
Wright D.K. and Hinson, M.D. (2012). A four-year longitudinal analysis measuring social and emerging media use in public relations practice. Paper presented to the 15th Annual International Public Relations Research Conference, Coral Gables, Florida, March 9.

Wright, D. K. \& Hinson, M. D. (2009b), An updated look at the impact of social media onpublic relations practice. Public Relations Journal, 3(2), 1-27.

Wright, D. K., \& Hinson, M. D. (2008b). How blogs and social media are changing publicrelations and the way it is practiced. Public Relations Journal, 2(2), 1-21.

Wright, D. K., \& Hinson, M. D. (2009a). Examining how public relations practitionersactually are using social media. Public Relations Journal, 3(3), 1-33.

Wright, D.K. (2001). The Magic Communication Machine: Examining the Internet's Impact on Public Relations, Journalism, and the Public. Gainesville, Florida: Institute for Public Relations and MCI Communications Corporation.

Wright, D.K. (2008). A global examination of the impact of social media and other new technologies on the practice of public relations. Presentation to theInternational Public Relations Association Public Relations World Congress, Beijing, China, November 14.

Wright, D.K. and Hinson, M.D. (2006a). "Weblogs and employee communication: Ethical questions for corporate public relations. Paper presented to the 9th Annual International Public Relations Research Conference, South Miami, Florida, March 10.

Wright, D.K. and Hinson, M.D. (2006b). How blogs are changing employee communication: Strategic questions for corporate public relations. Paper presented to the Public Relations Society of America International Conference, Salt Lake City, Utah, November 12.

Wright, D.K. and Hinson, M.D. (2007b). Assessing the impact blogs and social media are having on the communication process. Paper presented to the Educators Academy, Public Relations Society of America International Conference, Philadelphia, PA, October 28.

Wright, D.K. and Hinson, M.D. (2013). An updated Examination of Social and emerging Media Use in Public relations Practice: A Longitudinal Analysis Between 2006 and 2013. Public Relations Journal, Vol. 7. No.3, 1-38.

Wright, D.K. and Hinson, M.D.(2007a). Technology's impact on communication theory: Rethinking traditional communication models. Paper presented to the 10thAnnual International Public Relations Research Conference, South Miami, Florida, March 10.

Yoo, Kyung-Hyan and Jangyul Robert Kim (2013) How U.S. state tourism offices use online newsrooms and social media in media relations, Public Relations Review 39, 534-541.

Young, R. (2009). Social media: How new forms of communications are changing job search and career management.: Be Heard. Newsletter of the Toronto Chapter of the International Association of Business Communicators. January-February. 